\title{
Surgery for infected aneurysm of the aortic arch
}

\author{
Ron-Bin Hsu, MD, and Fang-Yue Lin, MD
}

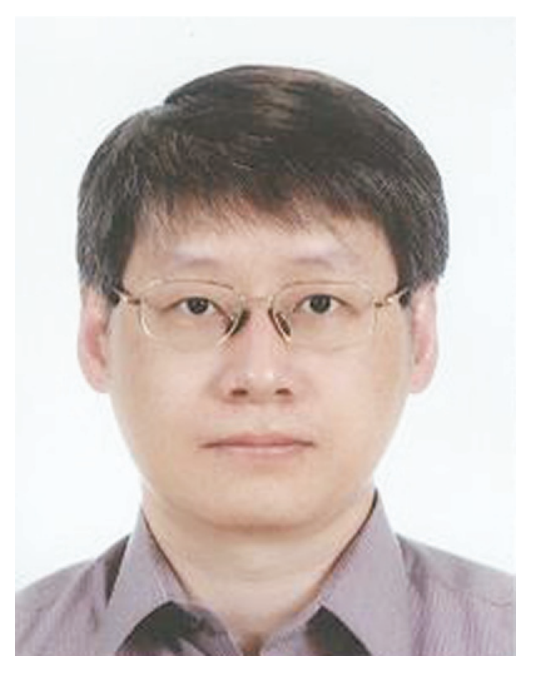

Dr. Hsu
From the Department of Surgery, National Taiwan University Hospital, National Taiwan University College of Medicine, Taipei, Taiwan, Republic of China.

Received for publication April 6, 2007; revisions received July 2, 2007; accepted for publication July 10, 2007.

Address for reprints: Fang-Yue Lin, MD, National Taiwan University Hospital, No 7, Chung-Shan S Rd, Taipei, Taiwan 100, ROC (E-mail: fylin1@ha.mc.ntu.edu.tw).

J Thorac Cardiovasc Surg 2007;134:1157-62 $0022-5223 / \$ 32.00$

Copyright @ 2007 by The American Association for Thoracic Surgery

doi:10.1016/j.jtcvs.2007.07.009
Objective: Infected aneurysm of the aortic arch is rare and can be fatal without surgery. We report our surgical experience with infected aneurysms of the aortic arch.

Method: We conducted a retrospective chart review.

Results: Between 1995 and 2006, 10 patients with infected aneurysms of the aortic arch were treated at our hospital. There were 8 men with a median age of 67.5 years (range, 50-79 years). The most common pathogen was nontyphoid Salmonella in 5 $(50 \%)$ patients, followed by Staphylococcus aureus in 2 patients. The site of infection was the aortic arch at the level of the brachiocephalic artery in 1, the left common carotid artery in 4, and the left subclavian artery in 5 patients. All patients underwent in situ graft replacement under deep hypothermic circulatory arrest. There was $1(10 \%)$ hospital death because of persistent infection. Major postoperative complications occurred in $7(70 \%)$ patients, with hypoxic encephalopathy occurring in 4 patients. Late prosthetic graft infection occurred in 1 patient, who died of massive gastrointestinal bleeding 4 months after the operation. Of the 9 patients with distal arch aneurysms, 3 were operated on through a sternotomy with a hospital mortality rate of $33 \%$ and an aneurysm-related mortality rate of $67 \%$. The operation was performed through a thoracotomy in 6 patients, with no hospital mortality and an aneurysm-related mortality rate of $17 \%$.

Conclusions: Infected aortic arch aneurysm was uncommon and nontyphoid Salmonella was the most common pathogen. Current treatment with in situ graft replacement was associated with high mortality and morbidity. Improvements in cerebral protection and surgical techniques should improve patient outcome.

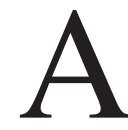

$\mathrm{n}$ infected aneurysm of the aorta and adjacent arteries is a rare but lifethreatening condition. ${ }^{1-10}$ The mortality rate is extremely high without surgical treatment. Infected aortic aneurysm is common in Taiwan and Hong Kong. ${ }^{1-16} \mathrm{We}^{11-16}$ have reported that with early surgical intervention and prolonged intravenous antibiotics, surgery with in situ graft replacement provides a good outcome. However, patients with infected aneurysms of the aortic arch were not included in previous studies. Only sporadic cases of infected aneurysms of the aortic arch have been reported, and the overall clinical outcome is poor. ${ }^{17-19}$ Herein, we report our surgical experience with infected aneurysms of the aortic arch.

\section{Patients and Methods \\ Setting}

The National Taiwan University Hospital (Taipei, Taiwan) is a 2000-bed tertiary care hospital. It serves an urban population of 2 million persons as both first-line and tertiary facilities. It serves also as a referral center for other hospitals in the country with a population of 22 million persons.

\section{Patients}

The study patient cohort was obtained from a retrospective analysis of the clinical data for patients with infected aneurysms of the aortic arch from September 1995 to September 2006. 
Patients with infection of the ascending aorta, descending thoracic aorta, and abdominal aorta were excluded.

\section{Diagnosis}

The diagnosis of infected aneurysm was made by a combination of clinical evidence of infection, imaging evidence of infected aorta, and/or pathologic evidence of inflammation. Clinically, infected aortic aneurysm was usually preceded by infected aorta or aortitis. Infected aorta was diagnosed with clinical evidence of infection (fever and leukocytosis) and periaortic soft tissue infiltration demonstrated by imaging study with either computed tomography or magnetic resonance imaging. ${ }^{20}$ Blood and tissue cultures were repeated to find the responsible microorganism. The diagnosis of infected aneurysm was further confirmed by the presence of frank pus during the operation and the presence of acute suppurative inflammation and/or bacterial clamps on pathologic examination. $^{21}$

\section{Medical Treatment}

As described previously, ${ }^{13,14}$ an intravenous antibiotic was given once the diagnosis was confirmed. For patients with Salmonella species infections, intravenous ceftriaxone (1000-2000 g every12 hours) was used. For patients with non-Salmonella infections, antibiotic use was based on culture results and sensitivity tests. In patients with a good response to antibiotic treatment (no fever, no localized pain, and declining white cell count), surgical intervention was considered after the infection was controlled. Imaging study was repeated if patients had a new symptom or sign suggesting aortic pseudoaneurysm formation (shock, a new localized pain, or a new palpable mass) or after complete antibiotic treatment. Early surgical intervention, which was defined as operation before the infection was controlled, was performed only in the situations of uncontrolled infection (persistent fever or septic shock) or evidence of impending aortic rupture (persistent pain, shock, or enlarging pseudoaneurysm formation on the repeated imaging study).

\section{Surgical Treatment}

Surgical management consisted of wide debridement of infected tissue, copious saline irrigation, and in situ repair with a Dacron graft. Homograft or antibiotic-immersed graft was not used because of unavailability.

The selected operative approach depended on the surgeon's preference. Median sternotomy was selected in patients with proximal aortic arch or distal aortic arch aneurysms. Cardiopulmonary bypass was instituted through arterial cannulation of the ascending aorta or right subclavian artery and venous cannulation of the right atrium. The reconstruction of the aortic arch and arch vessels was performed with the patient under deep hypothermic circulatory arrest. Methods of brain protection during circulatory arrest, including deep hypothermia alone, retrograde cerebral perfusion, and selective antegrade cerebral perfusion, also depended on the surgeon's preference. Left posterolateral thoracotomy was selected for patients with distal arch aneurysms. Cardiopulmonary bypass was instituted through cannulation of the femoral artery and femoral vein. Proximal aortic anastomosis was performed with the patient under deep hypothermic circulatory arrest. No adjunctive cerebral perfusion was used in patients treated by a thoracotomy approach.

Antibiotics were administered intravenously in the hospital for at least 6 to 8 weeks and until the clinical and laboratory parameters (fever, white cell count, and C-reactive protein) were within normal limits. Antibiotics were continued orally after discharge for least 6 months by surgeon's preference.

\section{Data Collection}

Data on age, sex, medical comorbidities, operation status, location of infected aneurysms, surgical procedure, and clinical outcome were collected retrospectively from medical records. Aneurysmrelated mortality was defined as a death caused by persistent infection or postoperative complications directly related to the operation. Death occurring more than 6 months after the operation was considered not aneurysm related.

\section{Results \\ Patient Characteristics}

From 1995 to 2006, 10 patients with infected aneurysms of the aortic arch were treated in our hospital. The patient demographics are shown in Table 1 . There were 8 men and 2 women with a median age of 67.5 years (range, 50-79 years). The medical comorbidities included hypertension in 4 patients, diabetes mellitus in 4 patients, chronic obstructive pulmonary disease in 1 patient, coronary artery disease in 3 patients, and pulmonary tuberculosis and end-stage renal disease with regular hemodialysis in 1 patient each.

Of the 10 patients, 9 were febrile at presentation and 4 had localized chest or back pain. No patient was in shock at the time of surgical treatment. Consciousness was disturbed in 3 patients, and hemoptysis and hemothorax were present in 1 patient each. One patient had an acute left middle cerebral artery ischemic stroke because of local compression of the left common carotid artery by an infected distal arch pseudoaneurysm. Two patients underwent emergency operations because of large aortic pseudoaneurysm and hemoptysis.

As shown in Table 1, all of our patients had aortic pseudoaneurysm or saccular aneurysm on the initial imaging study. The size of pseudoaneurysm ranged from 3 to 6.5 $\mathrm{cm}$ in maximal diameter. The site of infection was the proximal aortic arch at the level of the brachiocephalic artery in 1 patient, the distal aortic arch at the level of the left common carotid artery in 4 patients, and the distal aortic arch at the level of the left subclavian artery in 5 patients.

\section{Microbiology}

All patients had a positive blood or tissue culture. The most common responsible microorganism was nontyphoid Salmonella in $5(50 \%)$ patients followed by Staphylococcus aureus in $2(20 \%)$ patients and Escherichia coli, Streptococcus pneumoniae, and Klebsiella pneumoniae in 1 patient each. The serotypes of isolated nontyphoid Salmonella were 
TABLE 1. Patient demographics of infected aneurysms of the aortic arch and arch vessels

\begin{tabular}{|c|c|c|c|c|c|c|}
\hline $\begin{array}{l}\text { No. (sex, } \\
\text { age [y]) }\end{array}$ & Pathogen & $\begin{array}{l}\text { Location of } \\
\text { aneurysm }\end{array}$ & $\begin{array}{c}\text { Clinical } \\
\text { presentation }\end{array}$ & Medical diseases & Imaging finding & $\begin{array}{l}\text { Operation and extent of } \\
\text { arch replacement }\end{array}$ \\
\hline $1(\mathrm{M}, 67)$ & $\begin{array}{l}\text { Salmonella, } \\
\text { typhimurium }\end{array}$ & Level of LCCA & Fever & None & $\begin{array}{l}\text { Pseudoaneurysm, } \\
\quad 6 \mathrm{~cm}\end{array}$ & $\begin{array}{l}\text { In situ grafting; partial } \\
\text { distal arch }\end{array}$ \\
\hline $2(M, 57)$ & $\begin{array}{l}\text { Salmonella } \\
\text { choleraesuis }\end{array}$ & Level of LSCA & Fever, chest pain & HT & $\begin{array}{l}\text { Pseudoaneurysm, } \\
4.8 \mathrm{~cm}\end{array}$ & $\begin{array}{l}\text { In situ grafting; partial } \\
\text { distal arch }\end{array}$ \\
\hline $3(M, 58)$ & $\begin{array}{l}\text { Klebsiella } \\
\text { pneumoniae }\end{array}$ & Level of BCA & $\begin{array}{l}\text { Fever, loss of } \\
\text { consciousness }\end{array}$ & $\begin{array}{l}\mathrm{CAD} \text {, bacterial } \\
\text { meningitis }\end{array}$ & $\begin{array}{l}\text { Pseudoaneurysm, } \\
5.5 \mathrm{~cm}\end{array}$ & $\begin{array}{l}\text { In situ grafting; partial } \\
\text { proximal arch }\end{array}$ \\
\hline $4(\mathrm{M}, 79)$ & $\begin{array}{l}\text { Salmonella } \\
\quad \text { enteritidis }\end{array}$ & Level of LSCA & Fever & $\begin{array}{l}\text { Pulmonary tuberculosis, } \\
\text { DM, HT }\end{array}$ & $\begin{array}{l}\text { Pseudoaneurysm, } \\
5 \mathrm{~cm}\end{array}$ & $\begin{array}{l}\text { In situ grafting; total } \\
\text { arch (island) }\end{array}$ \\
\hline $5(F, 66)$ & $\begin{array}{l}\text { Salmonella } \\
\quad \text { choleraesuis }\end{array}$ & Level of LSCA & Fever & $\mathrm{DM}, \mathrm{HT}, \mathrm{CAD}$ & $\begin{array}{l}\text { Pseudoaneurysm, } \\
3 \mathrm{~cm}\end{array}$ & $\begin{array}{l}\text { In situ grafting; partial } \\
\text { distal arch }\end{array}$ \\
\hline $6(M, 79)$ & Escherichia coli & Level of LSCA & $\begin{array}{l}\text { Fever, loss of } \\
\text { consciousness, } \\
\text { chest pain }\end{array}$ & COPD, heart failure & $\begin{array}{l}\text { Pseudoaneurysm, } \\
\quad 6 \mathrm{~cm}\end{array}$ & $\begin{array}{l}\text { In situ grafting; partial } \\
\text { distal arch }\end{array}$ \\
\hline $7(\mathrm{M}, 78)$ & $\begin{array}{l}\text { Staphylococcus } \\
\text { aureus }\end{array}$ & Level of LCCA & $\begin{array}{l}\text { Fever, ischemic } \\
\text { stroke }\end{array}$ & Toxicoderma & $\begin{array}{l}\text { Pseudoaneurysm, } \\
5 \mathrm{~cm}\end{array}$ & $\begin{array}{l}\text { In situ grafting; total } \\
\text { arch (island) }\end{array}$ \\
\hline $8(M, 68)$ & $\begin{array}{l}\text { Staphylococcus } \\
\quad \text { aureus }\end{array}$ & Level of LSCA & Fever & DM, HT, CAD, uremia & $\begin{array}{l}\text { Pseudoaneurysm, } \\
5.5 \mathrm{~cm}\end{array}$ & $\begin{array}{l}\text { In situ grafting; total } \\
\text { arch (multi- } \\
\text { branched graft) }\end{array}$ \\
\hline $9(\mathrm{M}, 50)$ & $\begin{array}{l}\text { Salmonella } \\
\quad \text { enteritidis }\end{array}$ & Level of LCCA & $\begin{array}{l}\text { Fever, } \\
\text { hoarseness }\end{array}$ & None & $\begin{array}{l}\text { Pseudoaneurysm, } \\
\quad 4 \mathrm{~cm}\end{array}$ & $\begin{array}{l}\text { In situ grafting; partial } \\
\text { distal arch }\end{array}$ \\
\hline $10(F, 70)$ & $\begin{array}{r}\text { Streptococcus } \\
\text { pneumoniae }\end{array}$ & Level of LCCA & $\begin{array}{l}\text { Hemoptysis, } \\
\text { drowsiness }\end{array}$ & $\begin{array}{l}\text { DM, central pontine } \\
\text { myelinosis }\end{array}$ & $\begin{array}{l}\text { Pseudoaneurysm, } \\
6.5 \mathrm{~cm}\end{array}$ & $\begin{array}{l}\text { In situ grafting; partial } \\
\text { distal arch }\end{array}$ \\
\hline
\end{tabular}

$\angle S C A$, Left subclavian artery; $B C A$, brachiocephalic artery; $L C C A$, left common carotid artery; $D M$, diabetes mellitus; $H T$, hypertension; COPD, chronic obstructive pulmonary disease; $C A D$, coronary artery disease.

Salmonella cholerasuis in 2, Salmonella enteritidis in 2, and Salmonella typhimurium in 1 patient.

\section{Surgical Treatment}

All patients underwent in situ graft replacement. The median duration of preoperative antibiotic use was 8.5 days (range, 0-21 days). The treatment and outcome are summarized in Figure 1. The extent of arch replacement was partial proximal arch replacement in 1 patient, total arch replacement in 3 patients, and partial distal replacement in 6 patients (Table 1).

\section{Sternotomy}

The operation was performed through a median sternotomy in 4 patients ( 1 for proximal arch aneurysm and 3 for distal arch aneurysm). A 58-year-old man with a history of coronary artery disease had bacterial meningitis caused by Klebsiella pneumoniae. He had persistent fever and consciousness disturbance despite the use of intravenous ceftriaxone for 2 weeks. Shock developed, and an echocardiogram showed massive pericardial effusion. Chest computed tomography showed a huge pseudoaneurysm over the proximal aortic arch at the level of the brachiocephalic artery. Culture of the aspirated pericardial effusion indicated Klebsiella pneumoniae. He underwent replacement of the ascending aorta and proximal aortic arch and reimplantation of the brachiocephalic artery under deep hypothermic circulatory arrest and retrograde cerebral perfusion for 80 minutes. The postoperative course was smooth and his consciousness gradually recovered 1 month after the operation. The other 3 patients with distal arch aneurysms underwent total arch replacement through a median sternotomy. Arch reconstruction was performed with an arch island in 2 patients and multi-branched graft in 1 patient (Table 1). Methods of brain protection were retrograde cerebral perfusion in 1 patient and selective antegrade cerebral perfusion in 2 patients. The only hospital death occurred in a 78-year-old patient with an infected aneurysm of the distal aortic arch caused by methicillin-resistant Staphylococcus aureus. He underwent an urgent operation because of progressive left cerebral hemispheric ischemic stroke caused by localized rupture of the infected aneurysm and compression of the left common carotid artery. He died of early prosthetic graft infection and overwhelming sepsis 4 weeks after the operation. The other 2 patients had severe hypoxic encephalopathy after the operation and 1 patient died of multiple organ failure shortly after discharge.

\section{Thoracotomy}

The operation was performed through thoracotomy in 6 patients with distal arch aneurysm (Figure 1). They under- 


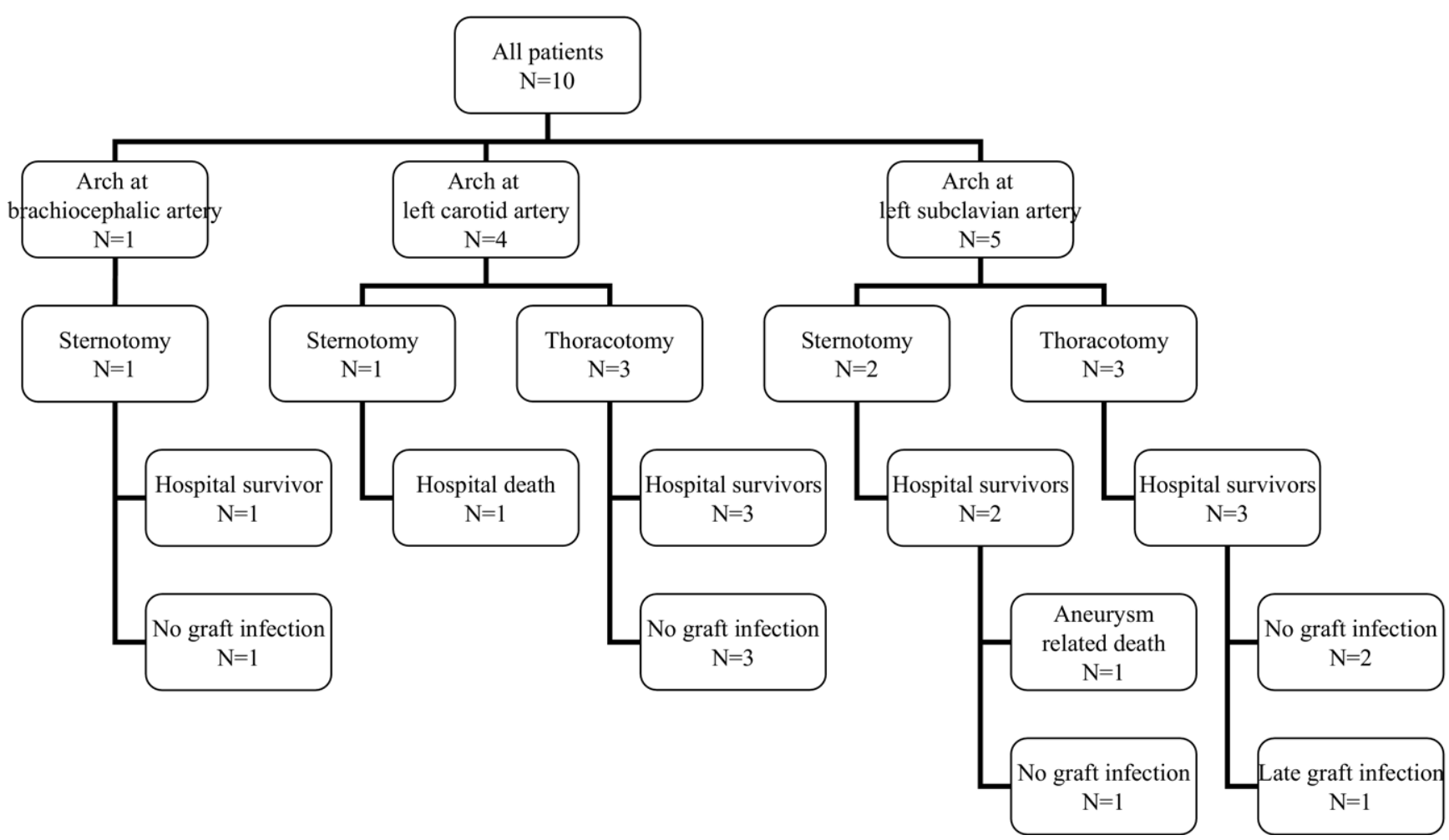

Figure 1. Treatment and outcome in patients with infected aneurysms of the aortic arch.

went in situ graft replacement and/or reimplantation of the left subclavian artery under deep hypothermic circulatory arrest. There was no hospital mortality. Two of them had postoperative hypoxic encephalopathy. A 70-year-old woman with an infected distal arch aneurysm caused by Streptococcus pneumoniae had hemoptysis and consciousness disturbance. The suspected aortobronchial fistula was untreated during the operation and she had lifelong oral antibiotic therapy.

Major postoperative complications occurred in 7 (70\%) of 10 patients. Hypoxic encephalopathy occurred in 4 patients, respiratory failure with prolonged ventilator support occurred in 2 patients, and reoperation for bleeding, sternal wound infection, nosocomial bacteremia, thoracotomy wound infection, and early prosthetic graft infection occurred in 1 patient each.

The follow-up ranged from 3 to 16 months. Late prosthetic graft infection occurred in a 57-year-old man with infected distal arch aneurysm caused by Salmonella cholerasuis. He underwent a successful operation after the preoperative use of ceftriaxone for 8 days. However, he died of aortoenteral fistula and massive bleeding 4 months after the operation.

Overall, the hospital mortality rate of in situ graft replacement was $10 \%$. The aneurysm-related mortality rate was $40 \%$.

\section{Discussion \\ Infected Aneurysm}

Early diagnosis and a combination of surgical intervention and prolonged antibiotic therapy are essential for survival in patients with infected aortic aneurysms. ${ }^{1-16}$ The reported hospital mortality rates range from $16 \%$ to $44 \% .{ }^{1-10}$ For fear of graft infection, early studies ${ }^{4-6}$ suggested that extraanatomic bypass grafting was the method of choice. Recently, more and more studies ${ }^{1-3,7-16}$ showed that in situ graft replacement was successful if prompt confirmation of infection was obtained, all possibly infected tissue was resected, and antibiotic therapy based on sensitivity data was administered for a prolonged period.

Infected aneurysms of the thoracic aorta are extremely uncommon. ${ }^{19}$ Infected aneurysms affecting the aortic arch provide an even more complex surgical challenge because the site of infection is difficult to approach and hypothermic circulatory arrest is usually required during the procedure. ${ }^{17-19}$ In addition, infected aneurysms of the aortic arch are not amenable to extra-anatomic reconstruction. It is usually difficult to remove the infected tissue completely in patients with infected aortic arch aneurysms. Therefore, such patients are likely to have persistent infection and high rates of postoperative complications related to the surgical procedures. In this current series, the hospital mortality rate of in situ graft replacement was not high. The lack of 
TABLE 2. Clinical outcomes of infected aneurysms of the aortic arch and arch vessels

\begin{tabular}{|c|c|c|c|c|c|c|c|}
\hline No. & $\begin{array}{l}\text { Antibiotic } \\
\text { used }\end{array}$ & $\begin{array}{l}\text { Preoperative } \\
\text { antibiotic } \\
\text { duration }\end{array}$ & $\begin{array}{l}\text { Operative } \\
\text { approach }\end{array}$ & $\begin{array}{l}\text { Duration of } \\
\text { DHCA }\end{array}$ & $\begin{array}{l}\text { Hospital } \\
\text { outcome }\end{array}$ & Postoperative complication(s) & Late outcome \\
\hline 1 & Ceftriaxone & $16 \mathrm{~d}$ & Thoracotomy & $88 \mathrm{~min}$ & Alive & $\begin{array}{l}\text { Respiratory failure, hypoxic } \\
\text { encephalopathy }\end{array}$ & Alive, $7 \mathrm{mo}$ \\
\hline 2 & Ceftriaxone & $8 \mathrm{~d}$ & Thoracotomy & $67 \mathrm{~min}$ & Alive & Wound infection & $\begin{array}{l}\text { Died at } 4 \text { mo of late } \\
\text { prosthetic } \\
\text { infection }\end{array}$ \\
\hline 3 & Ceftriaxone & $19 \mathrm{~d}$ & Sternotomy & $80 \mathrm{~min}$ & Alive & None & Alive, 13 mo \\
\hline 4 & Ceftriaxone & $0 \mathrm{~d}$ & Sternotomy & $93 \mathrm{~min}$ & Alive & Hypoxic encephalopathy & $\begin{array}{l}\text { Died at } 3 \text { mo of } \\
\text { multiple organ } \\
\text { failure }\end{array}$ \\
\hline 5 & Ceftriaxone & $14 \mathrm{~d}$ & Thoracotomy & $52 \mathrm{~min}$ & Alive & $\begin{array}{l}\text { Respiratory failure, nosocomial } \\
\text { bacteremia }\end{array}$ & Alive, 16 mo \\
\hline 6 & Ceftriaxone & $21 \mathrm{~d}$ & Thoracotomy & $40 \min$ & Alive & Hypoxic encephalopathy & Alive, $14 \mathrm{mo}$ \\
\hline 7 & Teicoplanin & $4 \mathrm{~d}$ & Sternotomy & $103 \mathrm{~min}$ & $\begin{array}{l}\text { Died of early } \\
\text { prosthetic } \\
\text { infection }\end{array}$ & Early prosthetic infection & \\
\hline 8 & Vancomycin & $11 \mathrm{~d}$ & Sternotomy & $36 \mathrm{~min}$ & Alive & $\begin{array}{l}\text { Hypoxic encephalopathy, } \\
\text { reopen for bleeding, sternal } \\
\text { wound infection }\end{array}$ & Alive, 7 mo \\
\hline 9 & Ceftriaxone & $5 d$ & Thoracotomy & $26 \mathrm{~min}$ & Alive & None & Alive, 16 mo \\
\hline 10 & Ceftriaxone & $1 \mathrm{~d}$ & Thoracotomy & $55 \mathrm{~min}$ & Alive & None & Alive, 7 mo \\
\hline
\end{tabular}

DHCA, Deep hypothermic circulatory arrest.

patients presenting with shock and the wealth of surgical experience in treating infected aortic aneurysm in our hospital contributed to the low mortality rate. ${ }^{13,14}$ Major postoperative complications included prosthetic graft infection and hypoxic encephalopathy. The incidence of prosthetic graft infection in treating infected arch aneurysm was high. Prosthetic graft infection occurred in 2 (1 early and 1 late) of all 10 surgically treated patients. The possible ways to improve the outcomes include appropriate and prolonged antibiotic therapy, aggressive surgical debridement, possibly use of multi-branched grafts, and placement of pedicled vascular tissue such as omentum or intercostal muscle to separate the graft from an infected bed of tissue. However, further studies are needed to prove these points.

A total of 9 patients with distal arch aneurysms were treated in this current series (Figure 1). The rate of postoperative hypoxic encephalopathy $(40 \%)$ was high because the infected tissue should be removed completely before conducting aortic anastomosis. The duration of deep hypothermic circulatory arrest was greater than 60 minutes in $60 \%$ of our patients.

The operation was performed through a median sternotomy in 3 patients. The hospital mortality rate was $33 \%$, the rate of postoperative hypoxic encephalopathy was $67 \%$, and the aneurysm-related mortality rate was $67 \%$. By contrast, the operation was performed through a thoracotomy in 6 patients. The rate of hospital mortality $(0 \%)$, the rate of postoperative hypoxic encephalopathy (33\%), and the aneurysm-related mortality rate $(17 \%)$ were comparatively low. The extent of arch involvement did not differ between our patients treated by thoracotomy or sternotomy. The possible reason for the better outcomes in the thoracotomy group was shorter hypothermic circulatory arrest times (Table 2). Measures to avoid postoperative hypoxic encephalopathy, such as selective antegrade cerebral perfusion, are mandatory to improve outcome in patients undergoing surgery for infected aortic arch aneurysms. Although intraoperative cerebral perfusion is difficult when patients are operated on through a thoracotomy, adjunctive cerebral perfusion should be used in patients treated via a sternotomy to minimize the risk of hypoxic encephalopathy.

\section{Microbiologic Analysis}

In Western countries, the most common organisms responsible for infected aneurysm are Staphylococcus aureus and Streptococcus species. ${ }^{1-10}$ In Taiwan, nontyphoid Salmonella is the most common pathogen. ${ }^{1-15}$ The mortality rate was $40 \%$ in Salmonella-infected patients who had combined medical and surgical treatment and $96 \%$ in patients who had medical treatment alone. ${ }^{22}$ Persistent or recurrent infection rate was 30\% in Salmonella-infected patients who survived surgery. ${ }^{23}$ Salmonella-infected aneurysms of the thoracic aorta are rare. In a collected series of 14 previously reported cases of Salmonella-infected aneurysms of the thoracic 
aorta, 10 patients underwent operation and $6(60 \%)$ patients died within 1 month after the diagnosis was made. ${ }^{17} \mathrm{In}$ fected aneurysms of the aortic arch are even more uncommon and have been reported in only 4 cases previously. Two patients died shortly after establishment of the diagnosis; 2 patients survived. ${ }^{17,18}$ In this current series, we added 5 patients with infected aortic arch aneurysms caused by nontyphoid Salmonella. There was no hospital mortality, and late prosthetic graft infection occurred in 1 patient.

Methicillin-resistant Staphylococcus aureus has emerged as a major nosocomial pathogen throughout the world. ${ }^{24} \mathrm{At}$ our institution, the prevalence of methicillin resistance among Staphylococcus aureus isolates recovered from all nosocomial infections increased from 4.3\% in 1981-1986 to $58.9 \%$ in 1993 to $1998 .{ }^{25}$ Methicillin resistance is associated with increased mortality in Staphylococcus aureus infection. ${ }^{26,27}$ In this current series, 2 patients had infection caused by Staphylococcus aureus and all staphylococcal isolates were methicillin resistant. The overall outcome was poor. One patient died of persistent infection, and the other had severe postoperative hypoxic encephalopathy.

In summary, the prognosis was poor in patients with infection caused by Staphylococcus aureus, which was methicillin resistant in most cases.

\section{Study Limitation}

The major limitations of this study are its retrospective nature and the lack of long-term follow-up information. Because of its retrospective nature, there was no consistent approach to these patients and the duration of preoperative antibiotic use was also variable. However, this study is the largest case series ever reported in the literature and provides useful information for the treatment of patients with infected aneurysm of the aortic arch.

In conclusion, infected aneurysm of the aortic arch was uncommon. Nontyphoid Salmonella was the most common responsible microorganism. Current treatment with in situ graft replacement only was associated with high mortality and morbidity. Aggressive surgical debridement, possibly use of multi-branched grafts and pedicled vascular tissue, and adjunctive cerebral perfusion probably will improve the outcomes.

\section{References}

1. Muller BT, Wegener OR, Grabitz K, Pillny M, Thomas L, Sandmann $\mathrm{W}$. Mycotic aneurysms of the thoracic and abdominal aorta and iliac arteries: experience with anatomic and extra-anatomic repair in 33 cases. J Vasc Surg. 2001;33:106-13.

2. Cina CS, Arena GO, Fiture AO, Clase CM, Doobay B. Ruptured mycotic thoracoabdominal aortic aneurysms: a report of three cases and a systematic review. J Vasc Surg. 2001;33:861-7.

3. Ihaya A, Chiba Y, Kimura T, Morioka K, Uesaka T. Surgical outcome of infectious aneurysm of the abdominal aorta with or without SIRS Cardiovasc Surg. 2001;9:436-40.
4. Moneta GL, Taylor LM Jr, Yeager RA, Edwards JM, Nicoloff AD, McConnell DB, et al. Surgical treatment of infected aortic aneurysm. Am J Surg. 1998;175:396-9.

5. Pasic M, Carrel T, Tonz M, Vogt P, von Segesser L, Turina M. Mycotic aneurysm of the abdominal aorta: extra-anatomic versus in situ reconstruction. Cardiovasc Surg. 1993;1:48-52.

6. Cull DL, Winter RP, Wheeler JR, Gregory RT, Snyder SO Jr, Gayle $\mathrm{RG}$, et al. Mycotic aneurysm of the suprarenal abdominal aorta. J Cardiovasc Surg. 1992;33:181-4.

7. Fillmore AJ, Valentine RJ. Surgical mortality in patients with infected aortic aneurysms. J Am Coll Surg. 2003;196:435-41.

8. Oderich GS, Panneton JM, Bower TC, Cherry KJ Jr, Rowland CM, Noel AA, et al. Infected aortic aneurysms: aggressive presentation, complicated early outcome, but durable results. J Vasc Surg. 2001;34:900-8.

9. Chiba Y, Muraoka R, Ihaya A, Kimura T, Morioka K, Nara M, et al. Surgical treatment of infected thoracic and abdominal aortic aneurysms. Cardiovasc Surg. 1996;4:476-9.

10. Cordero JA Jr, Darling RC 3rd, Chang BB, Shah DM, Paty PS, Leather RP. In situ prosthetic graft replacement for mycotic thoracoabdominal aneurysms. Am Surg. 1996;62:35-9.

11. Chan P, Tsai CW, Huang JJ, Chuang YC, Hung JS. Salmonellosis and mycotic aneurysm of the aorta. A report of 10 cases. J Infect. 1995; 30:129-33.

12. Wang JH, Liu YC, Yen MY, Wang JH, Chen YS, Wann SR, et al. Mycotic aneurysm due to non-typhi Salmonella: report of 16 cases Clin Infect Dis. 1996;23:743-7.

13. Hsu RB, Tsay YG, Wang SS, Chu SH. Surgical treatment for primary infected aneurysm of descending thoracic aorta, abdominal aorta and iliac arteries. J Vasc Surg. 2002;36:746-50.

14. Hsu RB, Chen RJ, Wang SS, Chu SH. Infected aortic aneurysms: clinical outcome and risk factor analysis. J Vasc Surg. 2004;40:30-5.

15. Luo CY, Ko WC, Kan CD, Lin PY, Yang YJ. In situ reconstruction of septic aortic pseudoaneurysm due to Salmonella or Streptococcus microbial aortitis: long-term follow-up. J Vasc Surg. 2003;38:975-82.

16. Ting AC, Cheng SW, Ho P, Poon JP, Tsu JH. Surgical treatment of infected aneurysms and pseudoaneurysms of the thoracic and abdominal aorta. Am J Surg. 2005;189:150-4.

17. Meerkin D, Yinnon AM, Munter RG, Shemesh O, Hiller N, Abraham AS. Salmonellamycotic aneurysm of the aortic arch: case report and review. Clin Infect Dis. 1995;21:523-8.

18. Schneider S, Krulls-Munch J, Knorig J. A mycotic aneurysm of the ascending aorta and aortic arch induced by Salmonella enteritidis. Z Kardiol. 2004;93:964-7.

19. Malouf JF, Chandrasekaran K, Orszulak TA. Mycotic aneurysms of the thoracic aorta: a diagnostic challenge. Am J Med. 2003;115:489-96.

20. Macedo TA, Stanson AW, Oderich GS, Johnson CM, Panneton JM, Tie ML. Infected aortic aneurysms: imaging findings. Radiology. 2004;231:250-7.

21. Miller DV, Oderich GS, Aubry MC, Panneton JM, Edwards WD Surgical pathology of infected aneurysms of the descending thoracic and abdominal aorta: clinicopathologic correlations in 29 cases (1976 to 1999). Hum Pathol. 2004;35:1112-20.

22. Soravia-Dunand VA, Loo VG, Salit IE. Aortitis due to Salmonella: report of 10 cases and comprehensive review of the literature. Clin Infect Dis. 1999;29:862-8.

23. Veraldi GF, de Manzoni G, Laterza E, Castaldini G, Dusi R, Fior F, et al. Extraintestinal infection by group C Salmonella: a case report and review of the literature. Hepatogastroenterology. 2001;48:471-4.

24. McGowan JE Jr, Tenover FC. Control of antimicrobial resistance in the health care system. Infect Dis Clin North Am. 1997;11:297-311.

25. Hsueh PR, Chen ML, Sun CC, Chen WH, Pan HJ, Yang LS, et al. Antimicrobial drug resistance in pathogens causing nosocomial infections at a university hospital in Taiwan, 1981-1999. Emerg Infect Dis. 2002;8:63-8.

26. Talon D, Woronoff-Lemsi MC, Limat S, Bertrand X, Chatillon M, Gil $\mathrm{H}$, et al. The impact of resistance to methicillin in Staphylococcus aureus bacteremia on mortality. Eur J Intern Med. 2002;13:31-6.

27. Soriano A, Martinez JA, Mensa J, Marco F, Almela M, MorenoMartinez A, et al. Pathogenic significance of methicillin resistance for patients with Staphylococcus aureus bacteremia. Clin Infect Dis. 2000; $30: 368-73$ 